\title{
BOURDIEU, TOURISM FIELD AND ITS IMPLICATIONS FOR GOVERNANCE OF TOURIST DESTINATIONS*
}

\author{
Thiago Duarte Pimentel *
}

\begin{abstract}
This theoretical essay aims to introduce the concept of field derivative from the Bourdeusian sociological theory to tourism and discuss some implications from it to governance of tourist destinations. For this it was done a brief review on Bourdieu's sociological theory and in the scarce papers in tourism area that tried to approximate this theoretical framework and tourism phenomena. In the results we present a proposal of transposition to the concept of field to tourism. In the same way it is showed the different possibilities that the pattern of relationships of the actors can set it up. It is argued that the actors in a tourism field needs to, directly or not, consider and deal with the positions of the others actors in the field. In conclusion if one wants to obtain a broader and efficient system of governance to tourist destination is necessary to analyze how structured the field is, who are the actors, what are their positions and what are their dispositions to act in some way. These elements will provide a matrix of relations to guide an empirical destination to identify and manage more accurately its constraints and capabilities to develop.
\end{abstract}

Keywords: Bourdieu. Tourism field. Tourist destination. Collective action.

\section{BOURDIEU, CAMPO TURÍSTICO E SUAS IMPLICAÇÕES PARA A GOVERNANÇA DE DESTINOS TURÍSTICOS}

\begin{abstract}
Este ensaio teórico tem como objetivo introduzir o conceito de "campo", derivado da teoria sociológica Bourdeusiana, no turismo e discutir algumas implicações disto para a governança dos destinos turísticos. Para tanto, foi feita uma breve revisão sobre a teoria sociológica de Bourdieu e também nos escassos artigos científicos na área do turismo que tentam aproximar este quadro teórico dos fenômenos turísticos. Nos resultados apresentamos uma proposta de transposição do conceito de campo para o turismo. No mesmo sentido, evidenciamos as diferentes possibilidades em que o padrão de relacionamentos dos atores do campo pode se configurar. Argumenta-se que os atores em um campo turístico precisam, diretamente ou não, considerar e tratar as posições dos outros atores no campo tanto para sua tomada de decisão quanto para sua ação. Em conclusão, se alguém desejar obter um sistema de governança mais amplo e eficiente para destino turístico é necessário analisar o quão estruturado o campo é, quem são os atores, quais são as suas posições e quais são as suas disposições para agir de alguma forma. Estes elementos fornecem uma matriz de relações para guiar e uma destinação turística empírica a identificar e gerenciar de forma mais precisa as suas limitações e capacidades para se desenvolver.
\end{abstract}

Palavras Chave: Bourdieu. Campo turístico. Destino turístico. Ação coletiva.

\section{BOURDIEU, CAMPO TURÍSTICO Y SUS IMPLICACIONES PARA LA GOBERNANZA DE DESTINOS TURÍSTICOS}

Este ensayo teórico tiene como objetivo introducir el concepto de "campo", derivado de la teoría sociológica Bourdeusiana, en el turismo y discutir algunas implicaciones de esto para la gobernanza de los destinos turísticos. Para ello, se hizo una breve revisión sobre la teoría sociológica de Bourdieu y también en los escasos artículos científicos en el área del turismo que intentan aproximar este cuadro teórico de los fenómenos turísticos. En los resultados presentamos una propuesta de transposición del concepto de campo para el turismo. En el mismo sentido, evidenciamos las diferentes posibilidades en que el patrón de relaciones de los actores del campo puede configurarse. Se argumenta que los actores en un campo turístico necesitan, directamente o no, considerar y tratar las posiciones de los otros actores en el campo tanto para su toma de decisión y para su acción. En conclusión, si alguien desea obtener un sistema de gobernanza más amplio y eficiente para el destino turístico es necesario analizar lo estructurado que es el campo, quiénes son los actores, cuáles son sus posiciones y cuáles son sus disposiciones para actuar de alguna manera. Estos elementos proporcionan una matriz de relaciones para guiar y una destinación turística empírica a identificar y gestionar de forma más precisa sus limitaciones y capacidades para desarrollarse.

Palabras Clave: Campo turístico. Destino turístico. Acción colectiva.

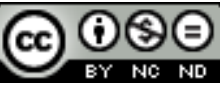

Licenciada por Creative Commons Atribuição Não Comercial / Sem Derivações/ 4.0 / Internacional

\footnotetext{
* This text was origanlly written to LXIII International Congress of the Association Internationale D'Experts Scientifiques Du Tourisme - AIEST Conference, in Izmir, Turkey (2013), where it was presented as oral comunication.

** PhD of Social Sciences / UFJF. Master in Administration / UFMG. Degree in Tourism / UFMG. Professor and researcher of full time at UFJF, postgraduate in Social Sciences, also in Management; and professor at bachelor of Tourism and Human Sciences. Member of the International Association of Scientific Experts in Tourism / AIEST. Visiting scholar in USA, Mx, Cuba, Ecuador. Chief Editor of Brazilian Anais of Tourism Studies / ABET and Latin American Magazine of Turismology / RLAT. Director of the Latin American Center of Turismology / CELAT and the Economic and Social Observatory of Tourism / OEST. CV: http://lattes.cnpq.br/9841188234449467 [ thiago.pimentel@ich.ufjf.br ]
} 


\section{INTRODUCTION}

This theoretical essay aims to introduce the concept of "field" derivative from the Bourdeusian sociological theory to tourism and discuss some implications from it to governance of tourist destinations. These heuristic and hermeneutical procedures are important because it seems furnish a better and structured theoretical framework to comprehend, analyze and explain tourism on its multiple levels of reality ${ }^{1}$.

The proposal presented here is the first one to approximate, in a systematic and more structured way, the sociological theory of Bourdieu and tourism. A brief review in literature of tourism show us that this one is a subtheorized area - or putting in Khun's words, a preparadigmatic area from a epistemological and theoretical point of view.

This question has consequences on practical order. It led us in a poor and bad understanding of tourism, as a systematic set of activities or as industrial and practical activity. A bad understanding prevents us of intervene on its functioning. Or when it (this intervention) happens it is in a trial and error way, what is limited and pre-scientific form to solve problems.

So, if the proposal presented here is contributive in some way, we hope it will be at least in two major aspects. The first one is its originality on its own subject. It can be viewed by a simple search on the major databases of scientific information on the world that there is a very little work on Bourdieu and tourism ${ }^{2}$ and moreover these papers are selective on their applications and an approximation between filed and tourism is yet to be done. So, firstly we think that this is a great opportunity to innovate and furnish a theoretical contribution.

The second one is in the sense that once made a sociological framework to/about tourism field it will lead us to understand how, why and what extended the different actors are put together and sustained their relations vis-a-vis to get their objectives and interests. Despite very contributions and efforts made, there are not yet an unified - or even a hegemonic - theory of tourism. So this strong theory borrow from a sociological theory can be useful in the sense to give

\footnotetext{
${ }^{1}$ Our starting point, in an ontological and epistemological issue, is the critical realism. Although developed in a proper way, this one is approximate since its born, in a sociological theory, with Margaret Archer, from/to the bourdieusian analysis.

2 We did a simple search on the following databases: Cambridge Journals; Web of Science/Web of Knowledge; Sage Journals; Scopus; Jstor; Emerald; and no one paper was found in this specific way of producing a proper reading of Bourdieu to tourism. It was found some (little) papers that use some concepts of Bourdieu theory but no one uses this framework as a hole to think the tourism as tourism field.
}

some parameters that will help us in the establishment of the corners for scientific objectivation of tourism.

\section{LITERATURE REVIEW}

The Despite his intellectual rigor in composition, selection and crossing a wide variety of concepts and influences from different philosophical traditions to create his own social thought, many commentators argue that the Bourdieusian system is relatively "simple" (JENKINS, 2006; THIRY - CHERQUES, 2006). It consists of a structural core of three concepts: field, capital and habitus. Maybe it could be added a fourth concept of symbolic violence. Around these concepts gravitates secondary categories, whose function is to specify and provide greater accuracy, increasing the potential explanatory his theoretical system (VANDENBERGHE, 1999; 2009, 2010b).

The social universe - or the theory of social fields is constituted by fields, which are spaces of objective relationships, each with its own logic that cannot be reduced to other fields. The social field can be seen as a system of relations between positions (which is the objective side of the field, the place in the social hierarchy that each agent occupies in the field), disposition (which are the subjective side of the field, given by the habitus and the propensity of agents to act according to what they have been internalized), and taken positions (referring to a posture in which those positions are expressed and whose principle lies in the structure and functioning of the field) (VANDENBERGHE, 2010b).

The idea of field was from the beginning linked to a highly conflictual conception of world, in which it is an ongoing battle for power, prestige and all kinds of capital (Vandenberghe, 2010b). In this sense the field is an area of objective relations between individuals and institutions that compete for domination of an particular leather (THIRY - CHERQUES, 2006). The metaphor of the field is invoked towards a social arena within which struggles and maneuvers on the access to specific resources (JENKINS, 2006).

She refers to a field of forces - as well as physical - for a given structure, pre-existing, which constrains the agents involved due to limited availability of resources and the space itself (physical and social) where they are located. It necessarily leads them to engage in social struggles, as their relative positions in the field, in order to have or increase their access to resources (or capital) existing in the field, culminating with the conservation or transformation of its initial structure (BORDIEU, 1996, p.50).

From the perspective of Bourdieu's genetic structuralism is necessary to recognize that the central 
focus of research is the analysis of objective structures, but not a fixed shape and tight as the classic Strauss structuralism, but linking the analysis of structures relations system, which are located spatio-temporally. Thus, the structure of the field designates an externality (which is not the field) and an interiority (the institutions and agents that exist and persist for difference). His analysis studies the field as the genesis of a product, i.e., the incorporation of preexisting structures. The structure of the field is given by the power relations between actors and institutions that fight for hegemony within the field, i.e. the monopoly of authority that grants the power to dictate rules (THIRY - CHERQUES, 2006).

Due to its objective analysis of structural relationships established, what is assumed by Bourdieu, fields can be analyzed regardless of the character of its occupants, i.e., as a system of objective relations. However, the social fields are not fixed structures or structured spaces of positions at a given time (JENKINS, 2006). Rather, they are products of the history of their occupants' positions and their dispositions that are in course to be reproduced. "Our position in a field designates how things not only consume, but also education, politics, the arts. Also determines the way we produce and accumulate (BOURDIEU, 1984, p. 210).

According to Bourdieu and Wacquant (2005) fields result from processes of social differentiation, and the way to be (re)experience the world, embedded in a process of constant evolution of society that gives rise to new fields in a continuous process of differentiation. Thus, the entire field is historical product and therefore has a nomos (set of laws that govern it) distinct. What determines the existence of a field and demarcate its boundaries are the special interests, economic and psychological investments made by different agents, endowed with a specific habitus convergent with that field, and institutions embedded in it, and who want a return on different forms of capital related to capital dominant in that field.

Every game presupposes rules and, in this sense, the field agents tacitly or explicitly share a consensus on the doxa of the field (BOURDIEU, WACQUANT, 2005). Although each field institutionalized its own object and its principle of understanding, social fields are not self-evident and need to be defined as such, which requires observation and analytical delimitation of the researcher on a particular segment of the social world.

The social fields have universal properties and characteristics, which does not prevent Bourdieu defend structural homology between fields. All fields have: a) habitus, class and subclass in which positions the agent, who is both a predisposition to act according to what he has assimilated throughout their learning process, b) a framework that refers to the system "goal" of relations between agents identified in the social space, $c$ ) the consensus opinion or doxa (replaces the Marxist concept of ideology), and refers to what about that all agents agree, therefore , as opposed to scientific, and includes everything that is accepted as "being like that", and d) the nomos, with respect to the laws that govern specific (THIRY CHERQUES, 2006).

Bourdieu (2008, p.131 - free translation) argues that "the social world is accumulated history, and therefore cannot be reduced to a concatenation of snapshots and mechanical equilibrium in which men play the role of particles interchangeable." So to address this accumulated history of the social world is that it introduces the concept of capital toward cumulative work, both in matter as so internalized or incorporated, as well as the accumulation of capital.

His central thesis is that when individuals or social groups appropriating capital privately or exclusively allow (also herons to this appropriation) the appropriation of social energy in the form of reified or living labor [objectified]. Thus, the capital stands as a force inherent in objective and subjective structures, and at the same time as a fundamental principle of internal regularities of the social world.

Schematically we can see that Bourdieu recognizes in principle three modes or forms of capital:

- the economic - which refers to relation in which such an economy, material possessions, income, of cash in short, every form of commercial value of assets gifted and capable of being liquidated;

- the cultural - knowledge, skills, information, etc., skillset intellectuals produced and transmitted by his family, school, etc. has 3 ways: (a) been incorporated as a provision in durable body (e.g. way of performing in public); (b) state the goal as asset ownership (e.g. artwork) and (c) institutionalized state (sanctioned institutions, ex. academic titles);

- the social - that refers to set of accesses social, relationship and networking.

The synthesis of these three types of capital that is so symbolic capital, which is the set of rituals of recognition, prestige, honor, etc. The relative position in the field is given by the volume of capital (of three) that the agent possesses. As the social structure generated by the distribution of different kinds of capital, any field can be divided into smaller regions, the subfields that behave like fields. 


\section{RESULTS AND DISCUSSION: ANALYSIS OF TOURISM FIELD}

The According to Bourdieu a field results from process of social differentiation. In tourism it is given by the access to mobility and travel emblematically occurred since II Industrial Revolution (cf. Hobsbawn, 2009). How is broadly written in tourism literature, this social differentiation emerges with the social practices of noblesse in that era. It was one of the forms by this class could sustain its status, by the investment in itself, in the acquisition of embodied cultural capital that could not be equally acquired by the bourgeoisie.

By your turn, this social practice provokes the emergence of a nomos (internal logic), what would lead to ulterior appearance of habitus, in the sense that travel is a form of obtain, accumulate and expand symbolic capital. Thus, travel becomes a form to acquire cultural capital.

Even more travel is seen as a exclusive form to acquisition by the embodiment (corporification), which means that only the individual could be retain this experience. This one would be personal and not transferable.

Gradually it becomes necessary to establish the boundaries of travels, the kind of travels and its senses. Travels become an object of contest. Different actors want to retain the monopoly about this social practice, even more they want impose their vision - by definition - about what is a travel and its meaning. This contest would lead us, e.g. in the beginning of XX century - to the attempts in the establishment of a definition of tourism. Note that is not by hazard the definition of tourism exclude laborious practices, because a form of cultural enrichment could not be embodied acquired if the body of a person is tied in a laborious practice.

Then a contest for the legitimacy of defining of tourism is imperative to delimitate what is a travel that promotes a cultural enrichment, and in this way become a sort of cultural capital, and what kind of travel is not expanding someone's knowledge.

As summarizes Bourdieu all the fields have:

(a) habitus, which in tourism is seen by the interjected value of a need in to expand knowledge by the embodied experience, what means a need to get contact whit new objects, places and people.

(b) framework, in tourist social practice given by producers, regulatory agencies, intermediaries organizations and people and/or organizations that does not pertain to tourism but furnishes goods and services. Nowadays this framework is well acknowledge by the systems theory perspective.

(c) doxa, which refers to a consensual opinion about tourism and travel. The doxa on tourism could see by the idea that travel is one human necessity and tourism is a way of knowledge and improve human potentials.

(d) nomos where travel is a form to obtain cultural capital.

In this context, and following Bourdieu's forms of capital, we argue that tourism is a subtype of capital derivate from the form of cultural capital. Once that cultural capital encompasses "knowledge, skills, information, etc.," which can be produced and transmitted different social groups and (a) been incorporated as a provision in durable body, (b) state the goal as asset ownership or (c) institutionalized; we can sustain that the tourism, by the specific operation of displacement of the individual from its original context (what is namely by travel), produces a provision in durable body which gradually becomes incorporated as a way of being (habitus).

Once identified the tourism field, what are its implications for governance on tourist destinations (TD)? In a simplified way grouping actors by the type of actions they perform on the field, we can see the possibilities of collective action (cf. figure 1).

Table 1: Relational matrix of possible links between the actors.

\begin{tabular}{|l|c|c|c|c|c|}
\hline Actor / relation & None relation & Private sector & Public setor & Civil society & $\begin{array}{l}\text { Convergence of } \\
\text { all actors }\end{array}$ \\
\hline Private sector & & 1 & & & \\
\hline Public setor & 0 & 2 & 4 & & \\
\hline Civil society & & 3 & 5 & 6 & \\
\hline
\end{tabular}

Source: prepared by the authors.

The first possibility is that there is no relationship between the actors (\# 0 ) and tourist activity does not happen at the destination, or be marginally exploited by specific companies from the private sector (e.g., charter bus to tour). This situation is very common in the early stages of developing a tourist destination (cf. Butler, 1980).
At a later stage in which there are already different private companies and organizations operating in the tourist destination (\# 1), it is possible to have a link between the private companies that offers, in a more complete and aggregated services that make up the tourism product for example, through partnerships between transportation companies and hosting. 
Another possibility is a joint effort between the private and public sector (\#2). In this case, the municipality or public agency responsible for tourism legislation and directs the activity, while the private sector is responsible for providing the services.

In (\# 3), instead of siding to the government, the private sector seeks support in civil society to improve the quality of tourism or explore possibilities of action together for the promotion of tourism and local quality of life. Here usually enter awareness raising, information and those left out of formal legislation and regulation on the activity.

Otherwise, tourism can present itself as a vocation yet to be explored and perhaps not even perceived by the private sector. In this case (\# 4), partnerships between public agencies occur at different levels of government in order to provide conditions for the exploitation of economic activity (e.g., through provision of public goods, such as creating access roads).

Another common form (\# 5) is to observe specific actions of municipalities and public agencies of tourism in order to try to raise awareness and attract the attention of other segments of society, for the development of local tourism. Here the government seeks to engage, rather than other public governmental society participation in order to ensure public benefits for the entire local society.

Although there may be forms of articulation between civil society entities, excluding the public and private sectors. Although it is more difficult, it can happen in the case where the local government is not acting nor for tourism development advanced to justify private offers products. Thus some communities have to develop their own initiatives, seek local social and economic development, often through tourism, due to lack of resources or other opportunities.

Finally, it is worth mentioning a possibility (\# 7), the articulation of three distinct groups. This is the ideal scenario but it hardly occurs. It would be the most suitable for the development and management of tourism.

\section{CONCLUSIONS}

Once that our objective was to introduce the Bourdeusian concept of field to tourism and discuss some implications from it to governance of tourist destinations, we can assert the proposal presented here brings at least two contributions. The first one is theoretical and deals to the framework of Bourdieu and its possibilities on theorizing of tourism. The second one refers to the implications from that theoretical framework. A better understanding of tourism, as a hole, can lead us to produce more accuracy tools and interventions on reality, e.g. on the context of management and governance of TD.

Thus, if we are correct and considering the necessity to identify, for effective management of the TD, who are the actors involved directly and indirectly in the tourism stakeholders, what are their interests and how they seek to achieve them; the Bourdieusian theoretical framework can furnish a fruitful avenue of studies, tools and applications.

\section{REFERENCES}

BOURDIEU, P. Algumas Propriedades sobre os Campos. In: ORTIZ, R. Questões de sociologia. Rio de Janeiro (RJ): Marco Zero, pp. 89-94, 1983.

BOURDIEU, P. As regras da arte: gênese e estrutura do campo literário. [Trad. Maria Lúcia Machado]. São Paulo (SP): Companhia das Letras, 1996.

BOURDIEU, P. From the King's House to the Reason of State: A Model of the Genesis of the Bureaucratic Field. Constellations, 11: 16-36., 2004. Doi: 10.1111/j.1351-0487.2004.00359.x

BOURDIEU, P. Las Estructuras Sociales de la Economía. $1^{\mathrm{a}}$ Ed. [ $1^{\mathrm{a}}$ Reimp. 2002] Buenos Aires: Ediciones Manantial SRL. 271p. 2001.

BOURDIEU, P. Las formas del capital: capital econômico, capital cultural y capital social. In: Bourdieu, P. Poder, Derecho y Clases Sociales. 2 Ed. (Spanish Edition). Desclée de Brouwer: 2008. 236p. Cap.4, pp.131-164.

BUCKLEY, W. A Sociologia e a Moderna Teoria dos Sistemas. São Paulo: Editora Cultrix, 1971.

BUTLER, R. The Concept of a Tourist Area of Life Cycle of Evolution: Implications for Management of Resources. Canadian Geographer, 19 (1): 5-12, 1980.

CROZIER, M. ; FRIEDBERG, E. Organisations et action collective. In: CROZIER, M. A quoi sert la sociologie des organisations? Paris: Éditions Seli Arslan, 1995.

DIECKOW, L. M. Turismo. Un abordaje micro y macro económico. (Edición electrónica gratuita), 2010. From: <http.www.eumed.net/libros/2010b/678/>. Access: 22 abril 2012.

DYE, T. Understanding public policy. (13th Edition). New York: Longman Press, 2009.

ESCALONA, F. M. Una Función Ignorada: la de producción de turismo (Segundo Memorial de Agravios). Revista Tursimo y desenvolvimento (TURyDES), 3 (7), 1-24, 2010.

HIRSCHMAN, A. O. Exit, Voice, and Loyalty: Responses to Decline in Firms, Organizations, and States. Cambridge, MA: Harvard University Press, 1970.

HOERNER, J-M.; SICART, C. S. La science du tourisme: précis franco-angais de tourismologie. (Edition bilingue, collection «Homo Turisticus»). Paris: Balzac Press, 2001.

JENKINS, R. Pierre Bourdieu: key sociologists. New York (USA): Routledge /Taylor \& Francis e-Library, 2006 [1992]. (Series: The Open University). 137p. 
KINGDON, J. Agendas, Alternatives, and Public Policies. Boston: Little, Brown Press, 1998.

KUHN, T. S. The structure of scientific revolutions. Chicago: University of Chicago, 1962. 172p.

PIMENTEL, M. P. C. A Institucionalização de Políticas Públicas de Turismo em Âmbito Municipal no Brasil. Unpublished master dissertation (Business Management), Federal University of Lavras, Lavras (MG), 2011.

PIMENTEL, T. D. Space, Identity and Power: outline of a morphogenetic and morfostatic theory to the sociology of organizations. 471f. Thesis (Ph.D.) Institute of Human Sciences, Federal University of Juiz de Fora, Juiz de Fora (MG), 2012.

THIRY-CHERQUES, H. R. Pierre Bourdieu: a teoria na prática. Revista de Administração Pública - RAP, Rio de Janeiro (RJ), 40 (1): 27-55, Jan./Fev, 2006.

VANDENBERGHE, F. Teoria Social Realista: um diálogo franco-britânico. Belo Horizonte: UFMG Press, 2010.

VANDENBERGHE, F. A era dos epígonos: a teoria social pós-bourdieusiana na França. In: VANDENBERGHE, F. Teoria Social Realista: um diálogo franco-britânico. Belo Horizonte (MG): Editora UFMG/ Rio de Janeiro (RJ): IUPERJ, 2010c. pp.85-110.
VANDENBERGHE, F. O esgotamento do novo movimento teórico e a era dos epígonos. In: Invenção do Contemporâneo, 2009, Campinas. CPFL. Palestra publicada em vídeo em: 09/10/2009 às 22:45:05. From: http://www.cpflcultura.com.br/site/2009/11/30/integrao-esgotamento-do-\%E2\%80\%9Cnovo-movimentoteorico $\%$ E2\%80\%9D-e-a-era-de-epigonos-fredericvandenberghe/. Access: 25 ago 2011.

\section{ACKNOWLEDGEMENT:}

The author acknowledges Conselho Nacional de Desenvolvimento Científico e Tecnológico CNPq/Brasil and Pró-Reitoria de Pesquisa da Universidade Federal de Juiz de Fora (PROPESQ/UFJF) by their financial support furnished, which were indispensable to presentation of this paper on the LXIII AIEST conference.

\section{Processo Editorial / Editorial Process}

Editor Chefe/Editor-in-chief: PhD Thiago D. Pimentel (UFJF).

Recebido em 30 de Junho de 2017; aceito em 31 de Agosto de 2017; publicado online em 31 de Outubro de 2017. Received on June 30, 2017; accepted on August 31, 2017, published online on October 31, 2017.

Artigo original / Original paper. Texto convidado / Invited paper. 